\title{
Effect of Biosynthesized Silver Nanoparticles using Achyranthes aspera Roots on Seed Quality Parameters of Groundnut
}

\author{
P. M. Smitha ${ }^{1 *}$, Sharanagouda Hiregoudar ${ }^{1}$, Udaykumar Nidoni ${ }^{1}$, \\ K. T. Ramappa and Sushilendra ${ }^{2}$ \\ ${ }^{1}$ Department of Processing and Food Engineering, College of Agricultural Engineering, \\ University of Agricultural Sciences, Raichur- 584 101, Karnataka, India \\ ${ }^{2}$ Department of Farm Machinery and Power Engineering, College of Agricultural \\ Engineering, University of Agricultural Sciences, Raichur- 584 101, India
}

*Corresponding author

\section{A B S T R A C T}

\section{Keywords}

Biosynthesis, Uttarani,

Achyranthes aspera, stability, silver nanoparticles, groundnut.

\section{Article Info}

Accepted:

12 August 2019

Available Online:

10 September 2019
Nanotechnology is considered as an emerging technology due to the possibility to advance well-established products and to create new products with totally new characteristics. Biosynthesised silver nanoparticles (Ag NPs) using A. aspera roots and standard $\mathrm{Ag}$ NPs were characterized by zetasizer, UV-Visible spectrophotometer and scanning electron microscope (SEM). Efficacy of biosynthesised and standard Ag NPs was attributed on quality parameters of Groundnut seed. The average particle size of Ag NPs was $50.37 \mathrm{~nm}$ (Standard) and $23.21 \mathrm{~nm}$ (Biosynthesized). The characteristic absorbance peak was observed at 407.40 and $420.80 \mathrm{~nm}$ for standard and biosynthesized Ag NPs, respectively. SEM images revealed that, both the standard and biosynthesized Ag NPs were spherical in shape. Ag NPs at $150 \mathrm{ppm}$ was found best in enhancing the seed quality parameters such as germination per cent, speed of germination, root length, shoot length, etc. The studies also revealed that, the effect of biosynthesized Ag NPs was on par with the standard Ag NPs in enhancing the groundnut seed quality. Hence, biosynthesized Ag NPs could be used as a new potential alternative for seed dormancy breaking in groundnut.

\section{Introduction}

Nanotechnology is a broad interdisciplinary area of research, development and industrial activity which has grown very rapidly all over the world for the past decade. It is considered as an emerging technology due to the possibility to advance well-established products and to create new products with totally new characteristics and functions in a wide range of applications. Nanoscience studies the phenomena, properties and responses of materials at atomic, molecular and macromolecular scales in general at sizes 
between 0.1 and $100 \mathrm{~nm}$ (Bhushan, 2004). Nanomaterials often show unique and considerably changed physical, chemical and biological properties compared to their macro scaled materials (Sharma et al., 2009).

Their performance depends critically on their size, shape and composition (Sathyavathi et al., 2010).

An array of physical, chemical and microbial methods has been used for synthesis of noble metal nanoparticles of particular shape and size (Balagurunathan et al., 2011).

Green synthesis provides advancement over chemical and physical methods as it is cost effective, environment friendly, easily scaledup and further there is no need to use toxic chemicals, high pressure and energy.

Groundnut (Arachis hypogaea) is a species in the legume or "bean" family. Groundnut seed is usually stored for a period of 9 to 12 months before sowing.

It is stored as unshelled pods and as kernels for different purposes. Both forms are vulnerable to attack by a plethora of storage pest after harvest.

However, seed viability is getting lost quickly due tothe production of free radicals by lipid peroxidation during storage.

The present technologies available to prolong the vigour and viability of groundnut seeds are not satisfactorily alleviating the practical problem. So an alternative simple and practicable seed treatment to control seed deterioration of groundnut is needed (Shylaand Natarajan, 2014).

Silver nanoparticles may be an alternative to control growth of insects and pests during storage (Al-Othman et al., 2014).

\section{Materials and Methods}

The experiments were carried out at Centre for Nanotechnology, Department of Processing and Food Engineering and at Seed unit, UAS, Raichur.

\section{Materials}

The Achyranthes aspera (locally called as Uttarani) roots were collected from University of Agricultural Sciences, Raichur. Groundnut seeds were collected from APMC, Raichur.

Standard silver nanoparticles were procured from Sisco Research Laboratories Pvt. Ltd., Mumbai, India.

\section{Biosynthesis of silver nanoparticles using Achyranthes aspera roots}

Initially, To prepare plant extract, $5 \mathrm{~g}$ of dried root powder and $100 \mathrm{ml}$ of distilled water was heated together at $60{ }^{\circ} \mathrm{C}$ for30 min in water bath and filtered through Whatmanfilter paper No. 1.

The filtrate was stored at $4^{\circ} \mathrm{C}$ for further experiments (Kalidasan and Yogamoorti, 2014). The root extract of $A$. aspera $(10 \mathrm{ml})$ was diluted with distilled water $(90 \mathrm{ml})$. Further, $1.5 \mathrm{mM} \mathrm{AgNO}_{3}(100 \mathrm{ml})$ solution was prepared and stored.

Prepared diluted plant root extract $(100 \mathrm{ml})$ and $\mathrm{AgNO}_{3}$ solutions were heated at $60{ }^{\circ} \mathrm{C}$ for 30 min in water bath, cooled and kept for further use.

For synthesis of silver nanoparticles, $85 \mathrm{ml}$ of $\mathrm{AgNO}_{3}$ solution was added to $15 \mathrm{ml}$ of prepared plant root extract. The mixture was heated $\left(45^{\circ} \mathrm{C}, 1 \mathrm{~h}\right)$ until chemical reaction took place resulting in colour change in the reactants from pale yellow to dark brown. 
The appearance of brown colour indicated the formation of silver nanoparticles (Plate 2) (Kalidasan and Yogamoorti, 2014).

\section{Characterization of biosynthesized and standard silver nanoparticles}

Characterization of the Standard and biosynthesised Ag NPs obtained using $A$. aspera root extract was performed. Zetasizer (ZETA Sizer, nano383, Malvern, England) was used to measure average particle size (nm) of Ag NPs. (Das et al., 2014).

UV-Visible spectrophotometer (Schimadzu, UV-1800, Kyoto, Japan) to check the absorbance of the Ag NPs was employed (Habibi et al., 2017). The morphological features of biosynthesized Ag NPs were studied by using scanning electron microscope (SEM) (Carl Zeiss Microscopy, EVO 10, Cambridge, UK). Magnification can be adjusted from about 1 to 30,000 times to get clear morphology of silver nanoparticles at the accelerating voltage of 5 to $30 \mathrm{kV}$ with working distance at $10 \mathrm{~mm}$ (Joseph et al., 2016).

\section{Priming of groundnut seeds}

The standard and biosynthesized silver nanoparticles were dissolved at different concentrations $(0,25,50,75,100,125$ and $150 \mathrm{ppm})$ in gum arabica and in de-ionized water solution, respectively.

Cleaned groundnut seeds were subjected to priming by soaking in silver nanoparticles solution at 1.00: 0.30 seed to solution ratio for about 4 hours.

The treated seeds were dried under the shade until seeds reached the moisture content of $7 \pm$ $1 \%$ (Khalaki et al., 2016).The seed quality parameters were determined by following the standard procedure described below.

\section{Seed germination test}

Seed germination test was carried out by paper towel method as prescribed by International Seed Testing Association (ISTA, 2013). Soaked (30 min) germination papers were used for germination test to keep the seeds moist. Fifty seeds were placed on germination paper in zig-zag manner and rolled from both sides. Likewise, four replications were made for each treatment. The rolled towels with seeds were secured with rubber band and placed in walk in seed germinator $\left(25 \pm 2{ }^{\circ} \mathrm{C}\right.$ temperature and $90 \pm 5 \% \mathrm{RH})$. The number of seeds germinated from each replication were counted daily up to 10 days and remaining seed parameters like root length, shoot length, seedling dry weight and vigour index I were taken on $10^{\text {th }}$ day.

\section{Percent germination and Speed of germination}

The number of seeds germinated in each treatment was counted then, germination percentage and Speed of germination was calculated using the following formulas (ISTA, 2013).

Seed germination(\%)

$$
=\quad \frac{\text { Number of normal seedings }}{\text { Total number of seeds }} \times 100
$$

Speed of germination $=\frac{X_{1}}{Y_{1}}+\frac{X_{2}-X_{1}}{Y_{2}}+\cdots \cdots+\frac{X_{n}-X_{n-1}}{Y_{n}}$

Where,

$X_{n}=$ No. of seeds germinated on $n^{\text {th }}$ day

$\mathrm{Y}_{\mathrm{n}}=$ No. of days from sowing on $\mathrm{n}^{\text {th }}$ day

\section{Root length and shoot length}

The root length was measured from the tip of primary root to the base of hypocotyls with the 
help of the scale and the mean root length was expressed in centimetres (ISTA, 1993).The shoot length was measured from the base of primary leaf to the base of hypocotyls and the mean shoot length was expressed in centimetres (ISTA, 1993).

\section{Seedling dry weight}

Ten randomly selected seedlings were taken in butter paper and dried in hot air oven at $70{ }^{\circ} \mathrm{C}$ for $24 \mathrm{~h}$.

Then, the seedlings were removed and allowed to cool in desiccators for $30 \mathrm{~min}$ before weighing in an electronic balance.

The average weight was calculated and expressed in milligrams (Almutairi and Alharbi, 2015)

\section{Vigour index I}

Vigour index I was worked out by multiplying the per cent germination (\%) and mean seedling length $(\mathrm{cm})$ as follows (Abdul-Baki and Anderson, 1973).

Seedling vigour index $\mathrm{I}=$ Per cent germination $(\%) \times$ Mean seedling length $(\mathrm{cm})$.

\section{Results and Discussion}

During synthesis, addition of root extract of $A$. aspera into the aqueous solution of silver nitrate led to the change in the colour of the solution from pale yellow to dark brown within reaction duration.

This might be due to the reduction of $\mathrm{Ag}^{+}$ ions, indicating the formation of $\mathrm{Ag}$ NPs. Excitation of the surface plasmon resulted strong light scattering by the electric field at a wavelength resonance which made the pale yellow solution turned to dark brown colour.
This might be due to the presence of bioactive compounds such as polyphenols, terpenoids, flavonoids, carbohydrates, vitamins and trace elements present in the plant extract played an important role in reduction of silver nanoparticles (Sivakumari et al., 2018).

\section{Characterization of silver nanoparticles}

\section{Zetasizer}

The characterization of standard and biosynthesized silver nanoparticles was done in terms of average particle diameter from the intensity distribution analysis by using zetasizer. The size distribution histogram of zetasizer indicated that, the size of standard and biosynthesized silver nanoparticles was 50.37 and $23.21 \mathrm{~nm}$, respectively (Fig. 1). The variation in particle size was probably due to change in climatic conditions during biosynthesis (Zainala et al., 2013).

These results are in good agreement with (Kalidasan and Yogamoorti, 2014) who reported that, the size of biosynthesized Ag NPs using A. aspera root extract was $105 \mathrm{~nm}$. Earlier it was reported that, an average particle size of biosynthesized silver nanoparticles were 19.60 and $25.50 \mathrm{~nm}$ using Pongamea pinnata seed and Achyranthes aspera leaf extract, respectively (Beg et al., 2016, Bobbu et al., 2016).

\section{UV-Visible spectrophotometer}

The reduction of $\mathrm{Ag}$ NPs in the aqueous solution of the silver complex during the reaction with the root extract of $A$. aspera was confirmed by the UV-Visible spectra. From Fig. 2, it is observed that, the surface plasmon resonance band was located at wavelength of 407.40 and $420.80 \mathrm{~nm}$ for standard and biosynthesized Ag NPs, respectively. This observed intense band was attributed due to the excitation of free electrons in the 
nanoparticles which indicated the presence of silver nanoparticles. Characteristic absorption peak at $413 \mathrm{~nm}$ for biosynthesized Ag NPs using A. aspera was reported earlier (Kalidasan and Yogamoorti, 2014).

It was also reported that, SPR band located at wavelength $450 \mathrm{~mm}$ for biosynthesized silver nanoparticles using Achyranthes aspera (Sivakumari et al., 2018).

\section{Scanning Electron Microscope (SEM)}

The clear magnified (8.07 KX) SEM image at the accelerating voltage of $10.00 \mathrm{kV}$ with working distance of $9.50 \mathrm{~mm}$, showed that, uniformly distributed standard and biosynthesized silver nanoparticles were in spherical shape (Fig. 3).

This might be due to the availability of different quantity and nature of capping agents present in the leaf extract (Srirangam and Rao 2017).

The present results are in good agreement with the findings of Sivakumari et al., 2018,Allafchian et al., 2016 and Premasudha et al., 2015 for biosynthesized Ag NPs (spherical shape) using A. aspera, Phlomis leaf extract and Eclipta alba leaf extract as reducing agent, respectively.

\section{Effect of standard and biosynthesized silver nanoparticles on seed quality}

\section{parameters of groundnut seeds}

Groundnut seeds when treated with standard and biosynthesized Ag NPs in different concentrations significantly outperformed compared to control in terms of per cent germination, speed of germination, shoot length, root length, seedling dry weight and vigour index. Significant differences were also observed between the doses.

\section{Percent germination and speed of germination}

Per cent germination and speed of germination of the groundnut seeds increased with increasing the concentration of standard and biosynthesized Ag NPs as compared to control (Table 1).

It is noticed that among all the treatments, 150 ppm recorded the maximum germination (91.75\%) and speed of germination (26.49). In all treatments, germination percentage and speed of germination of standard Ag NPs was on par with the biosynthesized Ag NPs. The reason for rapid germination could be due to the penetration of nanoparticles into the seed coat facilitating the influx of water inside the seed and activated the enzymes in early phase, thereby enhancing the speed of germination (Sridhar, 2012). Almutairi and Alharbi, 2015 found that, Ag NPs at 2000 ppm had increased germination speed (1.59 seeds/ day) for watermelon over the control (0.85 seeds/day).

\section{Root length and shoot length}

Nanoparticle treated germinated seeds exhibited maximum root and shoot length than control (Table 2).

Standard and biosynthesized Ag NPs treated seeds at $150 \mathrm{ppm}$ induced maximum root length i.e., 22.55 and $22.10 \mathrm{~cm}$, respectively compared to control $(15.81 \mathrm{~cm})$. In all the treatments, biosynthesized Ag NPs showed on par results with standard Ag NPs (Table 2). Also, standard and biosynthesized Ag NPs proved best by giving maximum shoot length (6.15 and $5.82 \mathrm{~cm}$, respectively) at the same dosage. A positive effect of Ag NPs on seedling growth of $V$. radiata was observed due to the enhanced uptake of water and nutrients by the treated seeds (Koizumi et al., 2008). 
These results were in good agreement with Pandey et al., 2014 who observed the maximum root length $(6.50 \mathrm{~cm})$ due to the application of Ag NPs (100 ppm) on Brassica
Juncea, The application of Ag NPs (1000 ppm) on onion seeds showed increased shoot length $(7.50 \mathrm{~cm})$ over the control $(5.40 \mathrm{~cm})$ (Anandaraj and Natarajan, 2017).

Plate.1 Achyranthes aspera root powder

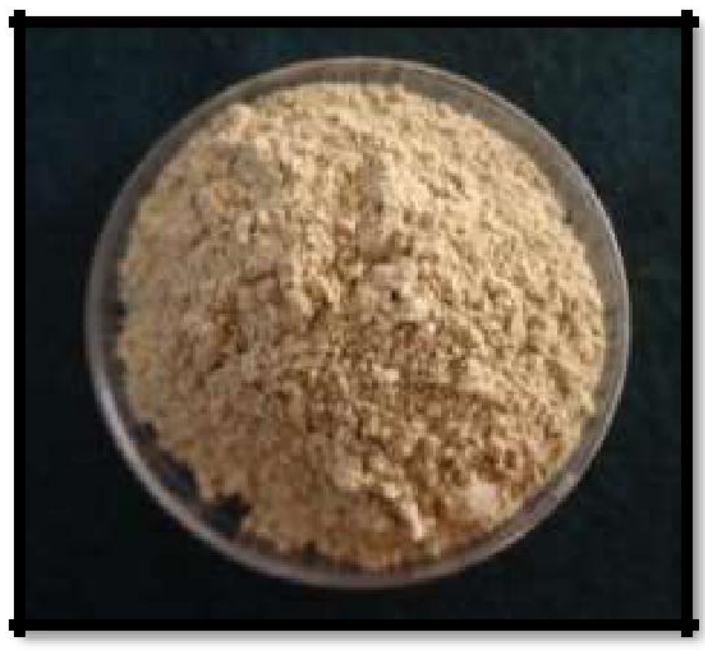

Plate.2 Biosynthesized silver nanoparticles

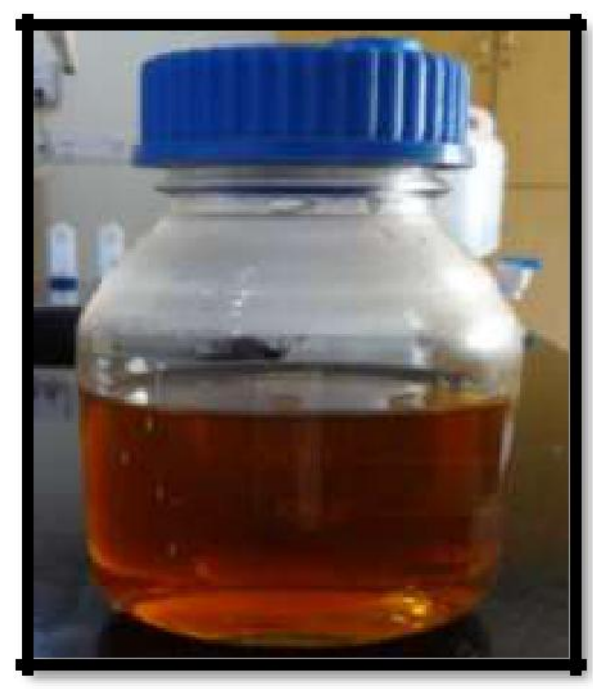




\section{Int.J.Curr.Microbiol.App.Sci (2019) 8(9): xx-xx}

Fig.1 Average particle size of a) standard and b) biosynthesized silver nanoparticles
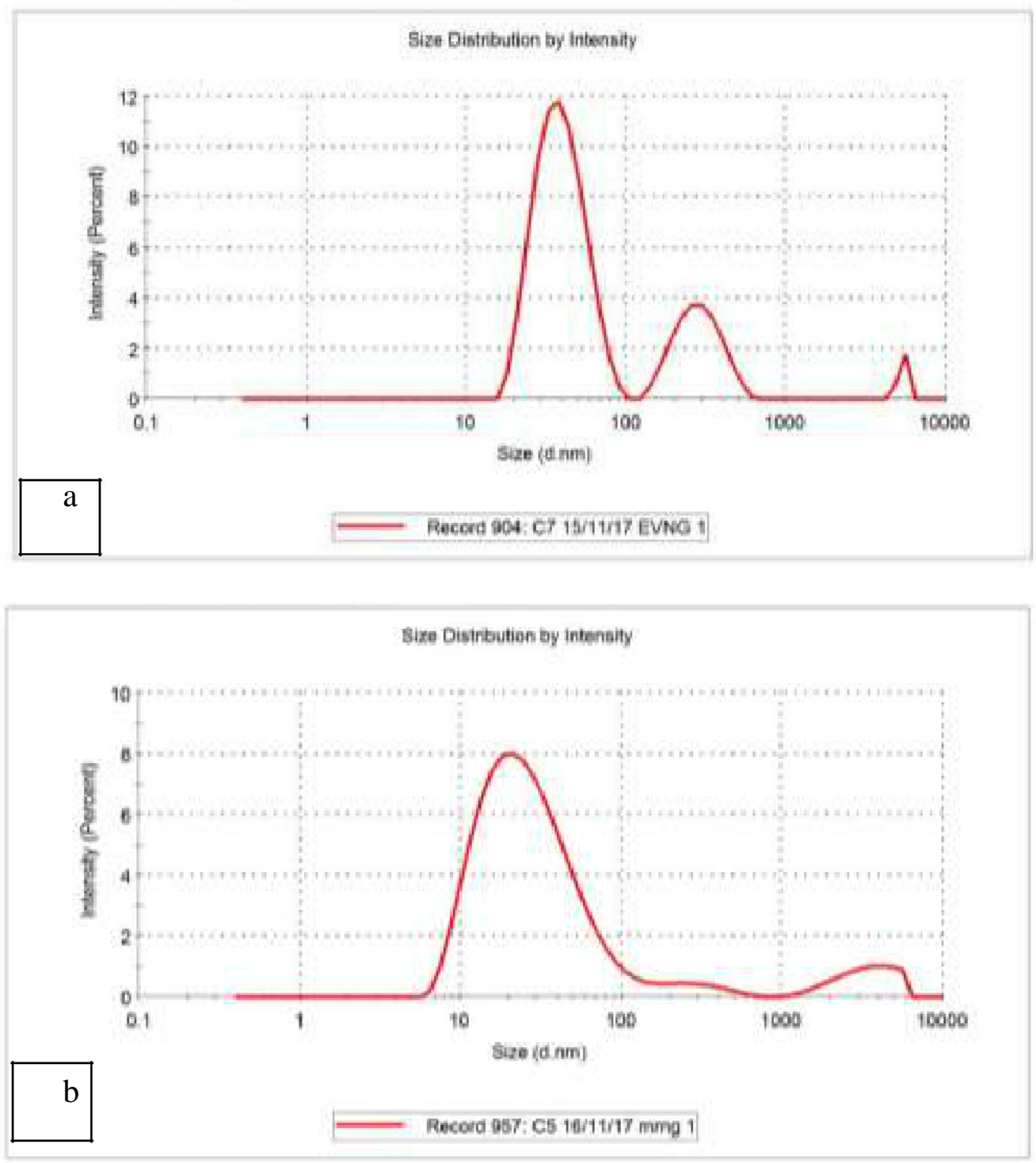
Fig.2 UV-Visible spectrum of a) standard and b) biosynthesized silver nanoparticles
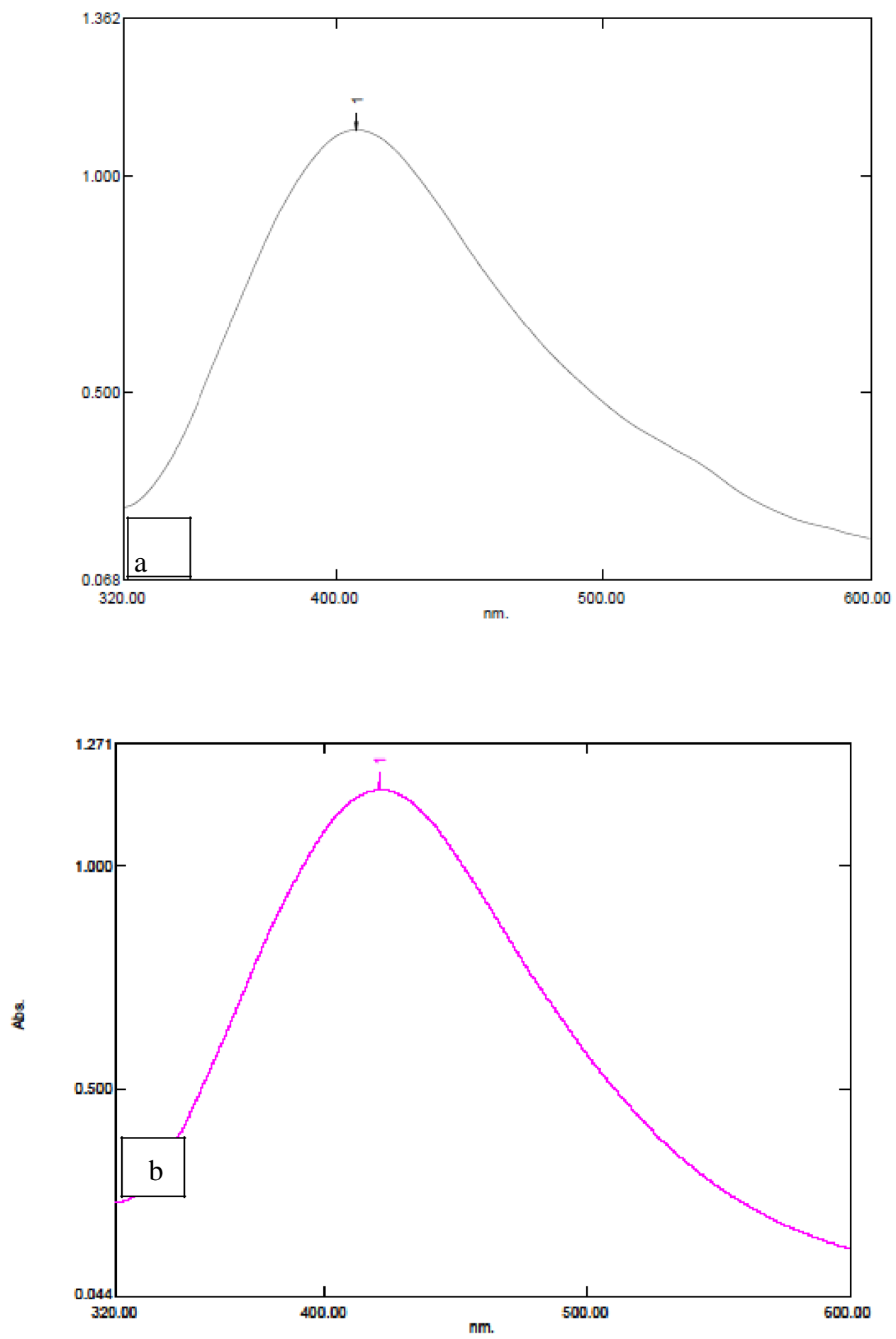
Fig.3 SEM image of a) standard and b) biosynthesized silver nanoparticles
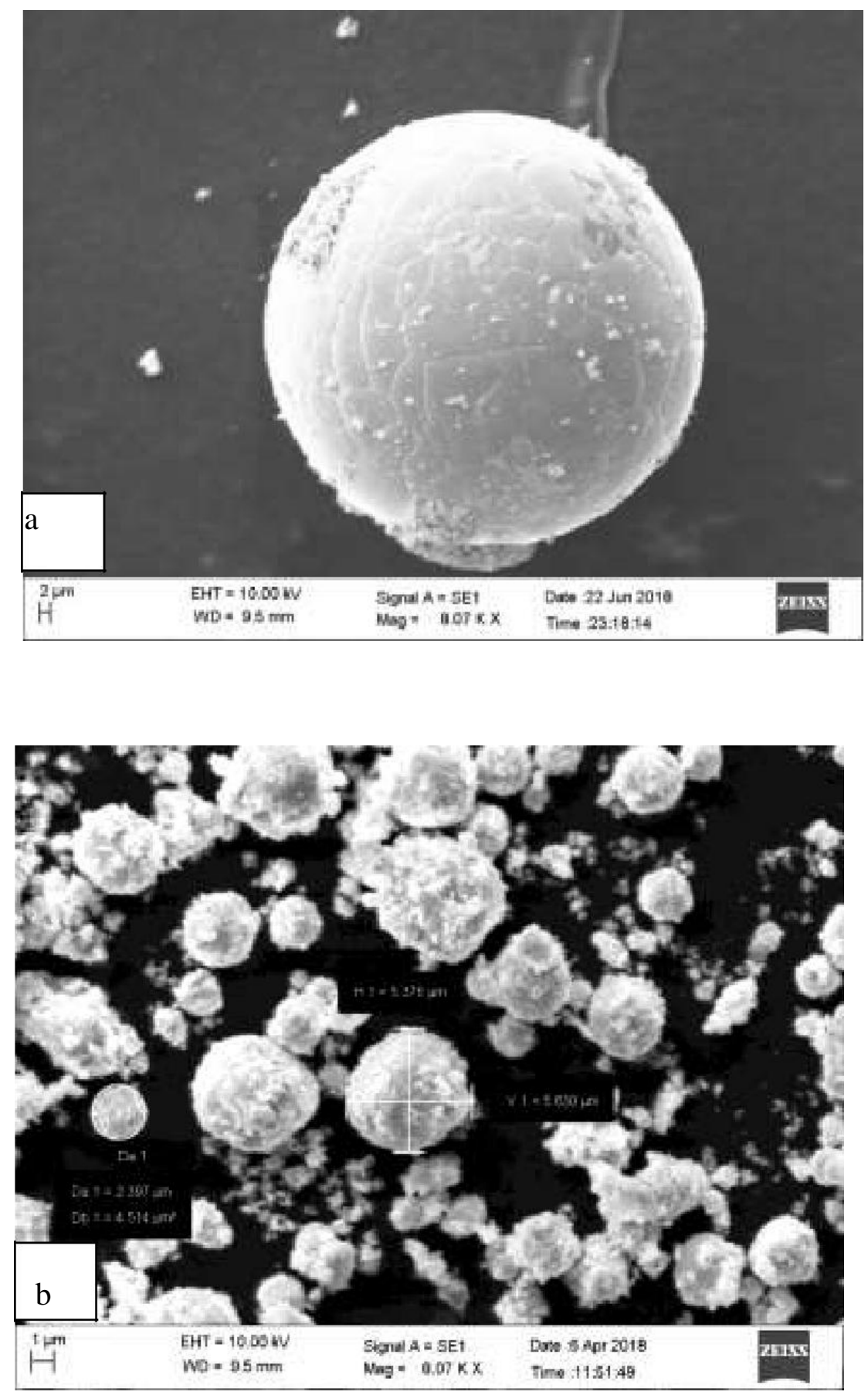
Table.1 Effect of Ag NPs on per cent germination and speed of germination of groundnut seeds

\begin{tabular}{|c|c|c|c|c|}
\hline $\begin{array}{c}\text { Concentration } \\
\text { (ppm) }\end{array}$ & \multicolumn{2}{|c|}{ Per cent germination } & \multicolumn{2}{c|}{ Speed of germination } \\
\hline & $\begin{array}{c}\text { Standard } \\
\text { Ag NPs }\end{array}$ & $\begin{array}{c}\text { Biosynthesised } \\
\text { Ag NPs }\end{array}$ & $\begin{array}{c}\text { Standard } \\
\text { Ag NPs }\end{array}$ & $\begin{array}{c}\text { Biosynthesised } \\
\text { Ag NPs }\end{array}$ \\
\hline $\mathbf{0}$ (control) & \multicolumn{2}{|c|}{77.28} & \multicolumn{2}{c|}{21.09} \\
\hline $\mathbf{2 5}$ & 81.14 & 80 & 23.32 & 23.25 \\
\hline $\mathbf{5 0}$ & 83.75 & 82.87 & 23.62 & 23.35 \\
\hline $\mathbf{7 5}$ & 85.15 & 84.12 & 24.63 & 24.39 \\
\hline $\mathbf{1 0 0}$ & 88.16 & 86.42 & 24.97 & 24.82 \\
\hline $\mathbf{1 2 5}$ & 91.02 & 89.37 & 26.34 & 26.28 \\
\hline $\mathbf{1 5 0}$ & 91.75 & 90.81 & 26.49 & 26.37 \\
\hline +SE (m) & & 0.97 & & 0.46 \\
\hline C. D at 1 \% & & 3.75 & & \\
\hline
\end{tabular}

Table.2 Effect of silver nanoparticles on root length and shoot length of groundnut Seeds

\begin{tabular}{|c|c|c|c|c|}
\hline \multirow{2}{*}{$\begin{array}{c}\text { Concentration } \\
\text { (ppm) }\end{array}$} & \multicolumn{2}{|c|}{ Root length $(\mathrm{cm})$} & \multicolumn{2}{|c|}{ Shoot length } \\
\hline & $\begin{array}{l}\text { Standard } \\
\text { Ag NPs }\end{array}$ & $\begin{array}{l}\text { Biosynthesised } \\
\text { Ag NPs }\end{array}$ & $\begin{array}{l}\text { Standard } \\
\text { Ag NPs }\end{array}$ & $\begin{array}{l}\text { Biosynthesised } \\
\text { Ag NPs }\end{array}$ \\
\hline O (control) & \multicolumn{2}{|c|}{15.82} & \multicolumn{2}{|c|}{3.88} \\
\hline 25 & 18.12 & 17.90 & 5.15 & 4.87 \\
\hline 50 & 19.42 & 18.37 & 5.37 & 5.07 \\
\hline 75 & 20.32 & 18.67 & 5.71 & 5.31 \\
\hline 100 & 21.25 & 19.32 & 5.72 & 5.50 \\
\hline 125 & 21.87 & 20.71 & 5.97 & 5.65 \\
\hline 150 & 22.55 & 22.10 & 6.15 & 5.82 \\
\hline$+\mathrm{SE}(\mathrm{m})$ & \multicolumn{2}{|c|}{0.64} & \multicolumn{2}{|c|}{0.29} \\
\hline C. D at $1 \%$ & \multicolumn{2}{|c|}{2.45} & \multicolumn{2}{|c|}{1.12} \\
\hline
\end{tabular}


Table.3 Effect of Ag NPs on seedling dry weight and vigour index I of groundnut seeds

\begin{tabular}{|c|c|c|c|c|}
\hline \multirow{2}{*}{$\begin{array}{c}\text { Concentration } \\
(\text { ppm })\end{array}$} & \multicolumn{2}{|c|}{ Seedling dry weight (mg) } & \multicolumn{2}{|c|}{ Vigour index I } \\
\hline & $\begin{array}{l}\text { Standard } \\
\text { Ag NPs }\end{array}$ & $\begin{array}{l}\text { Biosynthesised } \\
\text { Ag NPs }\end{array}$ & $\begin{array}{l}\text { Standard } \\
\text { Ag NPs }\end{array}$ & $\begin{array}{l}\text { Biosynthesised } \\
\text { Ag NPs }\end{array}$ \\
\hline 0 (control) & \multicolumn{2}{|c|}{1497} & \multicolumn{2}{|c|}{1520} \\
\hline 25 & 1792 & 1761 & 1886 & 1821 \\
\hline 50 & 1817 & 1790 & 2076 & 1944 \\
\hline 75 & 1864 & 1848 & 2217 & 2018 \\
\hline 100 & 1917 & 1880 & 2378 & 2145 \\
\hline 125 & 2025 & 1996 & 2535 & 2356 \\
\hline 150 & 2126 & 2052 & 2633 & 2536 \\
\hline$+\mathrm{SE}(\mathrm{m})$ & \multicolumn{2}{|c|}{13.13} & \multicolumn{2}{|c|}{63.94} \\
\hline C. D at $1 \%$ & \multicolumn{2}{|c|}{50.31} & \multicolumn{2}{|c|}{244.89} \\
\hline
\end{tabular}

\section{Seedling dry weight and Vigour index I}

The priming of silver nanoparticles on the groundnut seeds at different concentrations resulted in a significant increase in seedling dry weight. The seedling dry weight increased by 29.58 and $27.04 \%$ @ 150 ppm for standard $(2126 \mathrm{mg})$ and biosynthesized (2052 $\mathrm{mg})$ Ag NPs, respectively against control (1497).

The application of nanoparticles on seed enhanced the level of organic compounds such as protein, chlorophyll and phenols in the primed seeds. Therefore primed seeds showed increased seedling dry weight which might be due to better seedling length (Syriyaprabha et al., 2012).Similar results were also observed by Khalaki et al., 2016 through the application of silver nanoparticles on Thymus Kotschyanus.

From the data (Table 3), it is observed that, the higher vigour index I (2633) about $42.27 \%$ was recorded with standard Ag NPs at 150 ppm over the control, which was statistically on par with biosynthesized Ag NPs (2536) at $150 \mathrm{ppm}$. The results are in good agreement with those published by Shyla and Natarajan, 2014 who reported that, the application of $\mathrm{Ag}$ NPs on groundnut seeds increased vigour index by about $40.35 \%$ against control.

The current study revealed that the application of silver nanoparticles by priming method had significantly enhanced the seed quality of groundnut seeds at $150 \mathrm{ppm}$, in terms of seed germination, speed of germination, root length, shoot length, seedling dry weight and vigour index I. The seed quality parameters were concentration dependent.

Since the effect of treatment $\mathrm{T}_{4} @ 125$ and $\mathrm{T}_{5}$ (a) $150 \mathrm{ppm}$ were on par in both the case of standard and biosynthesized Ag NPs, lower dosage (125 ppm) was suggested for the seed treatment.

The effect of biosynthesized Ag NPs was on par with the standard Ag NPs in all the treatments. Hence, the biosynthesized Ag NPs 
could be used as a new alternative potential for seed dormancy breaking in groundnut.

\section{Acknowledgement}

The authors thank to the University of Agricultural Sciences, Centre for Nanotechnology, Department of Processing and Food Engineering and Seed unit, Department of Seed Science and Technology, Raichur, Karnataka, India to provide the facility to conduct the experimental work and also thanks to Indian Council of Agricultural Research (IARI) for the financial support for my research work.

\section{References}

Abdul-Baki, A. A. and Anderson, J. D., 1973, Vigour determination by multiple criteria.Crop Science, 13(2): 630-637.

Allafchian, A. R., Mirahmadi, S. Z., Jalali, S. A. H., Hashemi, S. S. and Vahabi, M. R., 2016, Green synthesis of silver nanoparticles using phlomis leaf extract and investigation of their antibacterial activity. Journal of Nanostructure in Chemistry, 6(4): 129135.

Almutairi, Z. M. and Alharbi, A., 2015, Effect of silver nanoparticles on seed germination of crop plants.International Journal of Biological, Biomolecular, Agricultural, Food and Biotechnological Engineering, 9(6):594-598.

Al-Othman, M. R., El-Aziz, A. R. M., Mahmoud, M. A., Eifan, S. A., El-Shikh, M. S. and Majrashi, M., 2014, Application of silver nanoparticles as anti-fungal and anti-aflotoxin $\mathrm{B}_{1}$ produced by Aspergillusflavus. Digest Journal of Nanomaterials and Biostructures, 9(1): 151-157.

Anandaraj, K. and Natarajan, N., 2017, Effect of nanoparticles for seed quality enhancement in onion.International
Journal of Current Microbiology and Applied Sciences, 6(11): 3714-3724.

Balagurunathan, R., Radhakrishnan, M., Rajendran, R. B. and Velmurugan, D., 2011, Biosynthesis of gold nanoparticles by actinomycete. Indian Journal of Biochemistry and Biophysics, 48(2): 331335.

Beg, M., Maji, A., Mandal, A. K., Das, S., Aktara, M. N., Pradeep, K., Jha. andHossain, M., 2016, Green synthesis of silver nanoparticles using Pongamiapinnata seed: Characterization, antibacterial property and spectroscopic investigation of interaction with human serum albumin. Journal of Molecular Recognition, 30(1): 1-8.

Bhushan, B., 2004, Handbook of Nanotechnology.

Bobbu, P., Netala, V. R., Aishwarya, S., Manohar, I. R., Reddy., Kotakadi, V. S. and Tartte, V., 2016, Rapid synthesis of silver nanoparticles using aqueous leaf extract of Achyranthesaspera and study of their antimicrobial and free radical scavenging activities. International Journal of Pharmacy and Pharmaceutical Science,8(5):

341-346.

Das, D., Yang, Y., Brien, O. J. S., Breznan, D., Nimesh, S., Bernatchez, S., Hill, M., Sayari, A., Vincent, R. and Kumarathasan, P., 2014, Synthesis and physicochemical characterization of mesoporous $\mathrm{SiO}_{2}$ nanoparticles.Journal of Nanomaterials,62(6): 11-12.

Habibi, B., Hadilou, H., Mollaer, S. and Yazdinezhad, A., 2017, Green synthesis of silver nanoparticles using the aqueous extract of Prangosferulaceae leaves. International Journal of Nano Dimensions,8(2): 132-141.

ISTA.,1993, International rules for seed testing. Seed Science and Technology, 20(4): 5-30.

ISTA., 2013, International rules for seed 
testing. Seed Science and Technology, 27(1): 25-30.

Joseph, A. T., Prakash, P. and Narvi, S. S., 2016, Phytofabrication and characterization of copper nanoparticles using Allium sativumand its antibacterial activity.International Journal of Scientific Engineering and Technology,4(2): 463472.

Kalidasan M. and Yogamoorti A 2014, Biosynthesis of silver nanoparticles using Achyranthusaspera and its characterization. International Journal of Nanomaterials and Biostructures, 4(1): 511.

Khalaki, M. A., Ghorbani, A. and Moameri, M., 2016, Effects of silica and silver nanoparticles on seed germination traits of Thymus Kotschyanusin laboratory conditions.Journal of Rangeland Sciences, 6(3): 221-230.

Pandey, C., Khan, C., Mishra, A., Sardar, M. and Gupta, M., 2014, Silver nanoparticles and its effect on seed germination and physiology in Brassica juncea L. (Indian Mustard). Plant Advanced Science Letters, 20(2): 1673-1676

Premasudha, P.,Venkataramana, M., Abirami, M., Vanathi, P., Krishna, K. and Rajendran, R., 2015, Biological synthesis and characterization of silver nanoparticles using Ecliptaalbaleaf extract and evaluation of its cytotoxic and antimicrobial potential. Indian Academy of Sciences,38(4): 965-973.

Sathyavathi, R., Krishna, M. B., Rao, S. V., Saritha, R. and Rao, D. N., 2010, Biosynthesis of silver nanoparticles using CoriandrumSativum leaf extract and their application in nonlinear Optics. Advanced
Science Letters, 3(4): 1-6.

Sharma, V. K., Yngard, R. A. and Lin, Y., 2009, Silver nanoparticles:Green synthesis and their antimicrobial activities. Advances in Colloid and Interface Science, $\quad$ 145(3): 83-96.

Shyla, K. K. and Natarajan, N., 2014, Customizing zinc oxide, silver and titanium dioxide nanoparticles for enhancing ground nut seed quality.Indian Journal of Science and Technology, 7(9): 1376-1381.

Sivakumari, K., Ashok, K. and Rajesh, S., 2018, Achyranthesaspera mediated green synthesis of silver nanoparticles. Indo American Journal of Pharmaceutical Sciences, 5(1): 64-73.

Sridhar, C., 2012, Effect of nanoparticles for the maintenance of tomato seed vigour andviability.M.Sc. (Agri.) Thesis, TNAU, Coimbatore (India).

Srirangam, G. M. and Rao. K. P., 2017, Synthesis and charcterization of silver nanoparticles from the leaf extract of Malachracapitata (L). Rasayan Journal of Chemistry, 10(1): 46-53.

Syriyaprabha, R., Karunakaran, G., Yuvakkumar, R., Rajendran, V. and Kannan, N., 2012.Silica nanoparticles for increased silica availability in Maize (Zea mays L.) seeds under hydroponic conditions.Current Nanoscience,8(6): 902-908.

Zainala, N. A., Shukor, S. R. A.,Wabb, H. A. A. and Razakb, K. A., 2013, Study on the effect of synthesis parameters of silica nanoparticles entrapped with rifampicin. Chemical Engineering, 32(7): 432-440.

\section{How to cite this article:}

Smitha, P. M., Sharanagouda Hiregoudar, Udaykumar Nidoni, K. T. Ramappa and Sushilendra 2019. Effect of Biosynthesized Silver Nanoparticles using Achyranthes aspera Roots on Seed Quality Parameters of Groundnut. Int.J.Curr.Microbiol.App.Sci. 8(09): 1188-1200. doi: https://doi.org/10.20546/ijcmas.2019.809.136 